\title{
Loving Wisely: Gender, Wisdom, and Ourania in Xenophon's Symposium
}

\author{
Elizabeth Casey ${ }^{1}$ and Namrata Narula\#
}

${ }^{1}$ Sage Hill School, Newport Beach, CA, USA

\#Advisor

\section{$\underline{\text { ABSTRACT }}$}

Xenophon's Symposium details a dinner party including Socrates in a manner similar to Plato's Symposium. Also similar to Plato's Symposium, Xenophon's Socrates speaks on the nature of love, and the different types of love; Ourania, heavenly, and Pandemos, common. How are gender and wisdom linked to the idea of Ourania, or heavenly love between souls, as depicted in Xenophon's Symposium? This paper will discuss whether or not women are capable of Ourania, which is traditionally reserved for only men. To answer this question, this paper will first show how wisdom is inherently tied to Ourania. This is because the love of souls involves knowledge of the soul, which is wisdom, or sophia. Then, it goes on to argue that virtues, including wisdom, can be taught. Finally, women are reintroduced, and it is argued that women can be taught wisdom. Consequently, this paperconcludes that women are capable of Ourania, for their souls can be wise.

\section{Loving Wisely}

In Xenphon's Symposium, Socrates addresses the topic of Ourania, or heavenly love, as it pertains to relationships between men. However, Socrates's arguments can be diversified when analyzed from a feminist perspective. I will examine the possibility of women engaging in the same type of love, and argue that they too are capable and worthy of heavenly love. I will detail the inherent linkage between Ourania and the soul through pederastia and selfknowledge. Socrates's points indicate that women can be taught virtues, and so I will first prove that wisdom can be taught like other virtues before arguing that women can be taught wisdom. And if wisdom can be taught, women's souls may be as worthy as men's of Ourania.

When it comes to literature regarding Xenophon, for the purposes of this paper I have focused on the literature of Vivienne Gray, Tim Rood, and Emily Baragwanath. Dr. Gray in particular edited the Oxford Readings in Classical Studies book on Xenophon and has additionally authored several articles on topics such as "Language and Expression" and "The Display of Wisdom". Much of the literature surrounding Xenophon has to do with his historical works, focusing on Xenophon as a historian and his interactions within Athens, Persia, and Sparta. The second major focus of secondary literature on Xenophon is on analysing his Socratic works, both as representations of Socrates' thought as well as philosophical works in their own right.

As stated above, Xenophon's Symposium falls within the sphere of his Socratic works. Gabriel Danzig provides an excellent overview in his article "Xenophon's Symposium." He notes that Symposium sets itself apart from Xenophon's other Socratic works in that, unlike the others, it is not primarily about Socrates, giving more weight to what the other guests have to say (Danzig 132). Bernhard Huss also provides analysis of Symposium in his article, "The Dancing Sokrates and the Laughing Xenophon, or the other Symposium," in which he discusses the unfortunately negative judgement of Symposium by nineteenth and twentieth century scholars, in part due to comparisons with the more famous Symposium by Plato (Huss 257). Other literature provides context and analysis of Xenophon and his interactions with his time. Articles by John W. I. Lee, Louis-Andre Dorion, Sarah Brown Ferrario, and Nino Luraghi provide this context of Xenophon in his time, among other Greek philosophers, Greek political thought, and Greek 
fourth-century historiography. All of these analyses help place Xenophon among his fellow writers in ancient Athens. Xenophon also had a unique style of writing, and Vivienne Gray and Tim Rood both analyze this in "Xenophon's Language and Expression" and "Xenophon's Narrative Style," respectively. In particular, Dr. Gray notes that Xenophon is hyper-conscious of word choice and is skilled at blending passages of "light and lovely subject matter with serious or dark themes" (Gray 224, 232).

When it comes to the topics discussed in this paper, namely gender and wisdom, there is again another section of literature dedicated to these themes. Dr. Gray provides an excellent analysis in "Xenophon's Symposium: The Display of Wisdom," in which she argues that the display of wisdom is the most prolific theme in the text, as it is present in every dialogue. When it comes to gender, Emily Baragwanath, Clifford Hindley, and Simon Goldhill all approach the theme from a romantic perspective, analyzing gender as it pertains to relationships. In "Xenophon's Foreign Wives" Baragwanath comments on the independence afforded to the wives of powerful political figures in Anabis, Cyropaedia, and Hellenica. All of the women referenced by Baragwanath serve as intermediaries between men, while also representing their interests (Baragwanath 44). Clifford Hadley's article, "Xenophon on Male Love," is of particular interest because it discusses the Greek tradition of pederasty and analyzes the differences between homosexual and heterosexual relationships in ancient Greece. However, there are few, if any, academics who explicitly link gender, wisdom, and Ourania.

There are certain terms that are crucial to this academic exploration which need to be clearly defined. At the crux of this argument lies the idea of Ourania. Ourania is one of the two personalities of Aphrodite, Aphrodite Ourania and Aphrodite Pandemos, the "heavenly and earthly," respectively (Xenophon 68). This paper will focus on the former and the type of love associated with her. Ourania, or heavenly love, governs the type of love that "feed[s] upon the soul," and is based more upon friendship than bodily love (Xenophon 68).

While Xenophon himself never explicitly states that Ourania may only exist between men, there are certainly other authors, both ancient and contemporary, that have said so. Plato, through the voice of Pausanias in his Symposium, in particular, referenced earlier in the text for his connection of sophia and pederastia, explains that there are two Aphrodites and so there are two types of love. The two goddess were initially distinguished by their parentage, "one, older obviously, is the daughter of Uranus and had no mother, and we call her 'Heavenly Aphrodite'; the younger is the daughter of Zeus and Dione and we call her "Common Aphrodite"" (Plato 11). According to Philip Krinks, because Heavenly Aphrodite only has a father, "the Heavenly Eros is exclusively homosexual," and the Common Aphrodite, who has parents of both genders, is heterosexual (Krinks 6). In summary, there are parallels that can be drawn between the arguments of both Pausanias and Krinks on the reasoning behind exclusively male Ourania.

In Plato's Symposium, Ourania as defined above is only ever referred to between men. Xenophon's text seems to support this opinion. However, neither text states explicitly that it may only exist between men; the reader draws this conclusion from the exclusive use of masculine pronouns when referring to Ourania. This is in direct contrast to the descriptions of common love, governed by Aphrodite Pandemos, which is referred to with both masculine and feminine pronouns. Xenophon and Plato are among the few Athenians who broach the topic, and as such their texts provide the most context surrounding how Athenians interacted with the concept of Ourania. The text indicates that, in the case of Ourania, wisdom makes one "worthier" of love (Xenophon 69). Consequently, this paper will explore whether wisdom, or sophia, alone is what makes one both worthy and capable of Ourania, regardless of gender. Since Xenophon does not explicitly state that this love may only be between men, it raises the question: are women capable of it? I argue that Xenophon's Symposium provides enough evidence to support that women are capable of this heavenly, soul-regarding love by demonstrating that women can in fact be wise, and wisdom is not an inherently masculine virtue, making heavenly love-which is based upon realizing the virtuous nature of the lovers soul-possible for women as well as men.

Before discussing women and their ability or inability to participate in heavenly love, it is important to first explore and establish the linkage between Ourania and wisdom. I would like to explore two significant routes that link Ourania to sophia; the first is through "friendship of the soul," or, as I will argue, pederastia, and the second 
through the pursuit of self-knowledge and how connecting with one's psyche is inherently tied to Ourania through sophia.

The soul is a rather nebulous idea and one that has evolved since Xenophon wrote his Symposium. Socrates was the first to use psyche to indicate the concept we refer to as "soul" today. However, at the time it lacked the Christian context it has been associated with in the past few centuries (Guthrie 147). As Socrates understood it, the psyche, now conventionally translated as soul, was the true self-the person-ness that inhabited the body (Guthrie 149). In this sense, it is similar to the modern understanding of the psyche but perhaps absent of divine connotations; psyche can be more closely understood as the locus of human virtues such as courage, and wisdom (Guthrie 149). According to Socrates, the pursuit of self-knowledge perfects the psyche, and these virtues would allow the psyche to "engage in the most intrinsically good... activity, contemplation" (Kamtekar 39). Johnstone argues that "the individual psyche is a particular incarnation of the cosmic Psyche, [and] if one follows one's own soul to its depths, one encounters the universal" (Johnstone 85). This context adds weight to Socrates's statement, "know thyself," where he advocates for self-knowledge and introspection; knowing oneself connects one to a greater, universal understanding.

Wisdom, in this text, is sophia, which, in post-socratic and Aristotelian philosophy, represents speculative rather than practical wisdom, phronesis. Sophia suggests "active knowledge" associated with a "craft," which indicates that wisdom is not a passive virtue but a skill that one works towards in pursuit of something (Johnstone 29). This is the virtue that Kamtekar argues leads to contemplation and self-knowledge, which in turn leads to a more actualized psyche and deeper understanding of wisdom. Ourania, the heavenly love between psychae, is inherently linked to wisdom as it pertains to self-knowledge.

Ancient Greek family life was vastly different from the present-day. The single family household had become standard a relatively short period of time before, and, as a result, marriage had a different context. Men and women existed in almost entirely distinct spheres of life, with the only crossover being the home, and as such respectable women were not "accessible", as in they were not as active in public life (Lear and Cantarella 3). Pederasty was a common practice in ancient Greek culture. There is some argument about the advent of the Greek pederastic tradition, some citing a military custom and others claiming it satisfied the "need to court and be accepted" (Lear and Cantarella 3). Regardless of how it began, there is enough evidence to indicate that ancient Greek aristocrats participated in a homoerotic, if not homosexual, courtship practice that involved a romantic relationships. These were generally between an older man, or erastes, and a younger boy, usually in his teens, or eromenos. This "prevailing bisexuality meant that two complementary institutions coexisted, the family taking care of what we may call the material side, pederasty (and the courtesan) the affective, and to a degree the intellectual, side of a man's intimate life" (Okin 2). As women were not considered intellectual or social equals in contemporary context, a partnership as a meeting of equals, between husband and wife was almost unheard of; some men sought such fulfillment from elsewhere in their peer group. Not only did pederasty provide this intellectual partnership, but it also provided mentorship for the eromenos, for whom the erastes served as a role model (Lear and Cantarella 104).

This tradition of pederastia harkens back to the friendship of the psyche as described by Xenophon. Ourania encapsulates the idea of a love that is more metaphysical than not, heightened to the most immortal parts of what it is to be human. Cantarella argues that, "there is a persistent, if ambiguous, tradition in Greek literature of idealizing pederasty and associating it with an inter-related set of social ideals" holding pederastic relationships to seemingly higher intellectual standards (Lear and Cantarella 92). In Plato's Symposium, Pausaunias indicates that a pederastic relationship can either be heavenly or vulgar (common), and that such relationships may only be heavenly "when the lover and beloved have the same objective - the erastes leading the boy to wisdom, [and] the boy seeking to attain it" (Cantarella 40, Plato 16). Here is an explicit link between wisdom and heavenly love; this passage goes on to indicate that Pausanias believed only pederastic relationships are capable of Ourania. Commonly held beliefs during the time surrounding women's intellectual capability and social mobility meant that the men writing these texts on Ourania did not address the question of whether or not women could be a part of such a relationship. This paper addresses whether or not Xenophon's text provides evidence that women are capable of Ourania, not that Xenophon himself believed so. Pausanias provides an excellent addition to the link between Ourania and wisdom. To summarize, 
a pederastic relationship is only honorable or heavenly if the mentor leads the mentee towards wisdom (Lear and Cantarella 40).

Secondly, Ourania cannot be separated from the idea of psyche and subsequently sophia. As previously outlined, the psyche is the true self and is the part of a person that resides in one's body (Guthrie 149). To improve the psyche, one seeks wisdom and thought as they are "its [the soul's] proper virtue" (Guthrie 150). Xenophon's Socrates, during a speech on heavenly love, states that as the psyche makes its "onward course towards deeper wisdom, [it] grows ever worthier of love" (Xenophon 69). Here, again, wisdom is almost a prerequisite for Ourania-the psyche must be virtuous (wise) to be considered worthy of Ourania. So, it seems that for women to be capable of Ourania, they must first be wise.

In order to argue that women can be wise, I will first argue that wisdom itself can be taught, and go on to prove that women can be taught virtues. When I argue that wisdom can be taught, I mean it in a way dissimilar to sophistry. Socrates was almost scandalized by sophistry as bastardized imitations of the highest virtue, wisdom, because they taught a different understanding of wisdom that was more performative than the Socratic one. To Socrates, "wisdom [is] comprise[d] of self-knowledge, and so the quest for it is fundamentally a matter of examining and caring for one's own psyche" (Johnstone 135). This journey towards self-knowledge is a highly personal one that requires deep reflection and introspection; it cannot be explicitly taught in the traditional sense, rather it must be learned through experience, which may be led by a mentor. Socrates himself asks in Symposium, "why should [wisdom] not be learnt as well as other things?" (Xenophon 13). Johnstone argues that acquiring wisdom is "simply a matter of learning to "hear it"' (Johnstone 61). Johnstone implies that wisdom is an inherent ability or virtue that everyone can access. However, most lack the ability to tap into it, and therefore benefit greatly from a mentor. In Listening to the Logos, Johnstone continues:

It would seem that wisdom comes to one who is taught from an early age to learn through the senses how the world-process operates at the macroscopic level, and then to perceive through the intellect those underlying realities that are beyond senses... to apprehend this fact and its implications is to have wisdom.

(Johnstone 78)

Therefore, wisdom, as Socrates believes it to be, may not be taught in the commonly accepted way of his time, sophistry. Sophistry really taught eloquence, not sophia. To Socrates, the virtues taught by Sophists are not true virtues, because Sophists themselves were not wise. Their very profession, to teach virtues to young boys, was counter-intuitive, because a man who is truly wise would not embark on such an endeavor because wisdom cannot be taught to those who are unwilling to work towards it, and cannot be bought. In the text, Socrates challenges Callias, a man taught by Sophists, to exhibit his wisdom to all present (Xenophon 22). This challenge then evolves into a sharing of what the men present would consider themselves the most proud of, and Callias named his ability to "make [his] fellow-mortals better" (Xenophon 23).

Finally, we are able to add women back into the discussion of wisdom, worthiness, and heavenly love. Before I go on to discuss the intersection of those themes, I must attempt to see if the text configures wisdom as an exclusively masculine virtue, and if not, whether women are included in this ideal. At the beginning of the party described in the text, there are two performers set to entertain the guests. These performers include a young girl who successfully performs incredible feats, including flipping and somersaulting through knives with amazing precision, never once injuring herself. After witnessing this spectacle, Socrates remarks that "none of the present company, I take it, who have watched this spectacle will ever again deny that courage can be taught" (Xenophon 15). This challenge implies that courage can be taught to women, for here he is referencing the courage of the female performer. Kamtekar references Cicero when he says that there is "a close connection between virtue-comprising wisdom, courage, justice, and moderation" (Kamtekar 29). Here wisdom and courage are closely linked as similarly significant virtues. Once Socrates states that women can be taught courage, he then goes on to challenge those present to "teach [their wives] whatever [they] would have them know as [their] associates," indicating that he believes women should be educated in this sphere if not also others, similarly to men. 
So, if wisdom can be taught, and women can be taught virtues, and wisdom itself is a virtue, then it stands to reason that women can be taught wisdom. And if the pursuit of sophia is what makes a psyche worthy and capable of Ourania, then wise women may be capable of Ourania.

Any woman willing and able to pursue wisdom may be capable of engaging in Ourania. This paper has offered commentary on a gap in the literature analyzing Xenophon. It hopes to have established that Ourania is intrinsically linked to Socratic wisdom, sophia. It also shows that women may be wise, and therefore capable and worthy of engaging in Ourania. Xenophon provides the stepping stones of this analysis, and this paper aims to bridge the gaps and move beyond what is written explicitly by bringing these ancient ideas of love into the modern world. This paper belongs to the fields of both philosophy and gender studies. Current societal understandings of gender stem from concepts established by Socrates and his contemporaries. It proves fruitful to analyze these concepts with a critical eye. If men's and women's psychae are equal, as I argue, and women are in fact capable of wisdom, what does that mean for our understanding of ancient virtues? And if Xenophon did believe that Ourania was only between men, what are the implications of that? If the highest form of love exists between men alone, does this love enjoin sexual expression, and thereby is homosexuality a more valued ideal than heterosexuality in this regard? These are only some of the topics that merit further interdisciplinary research into Xenophon and Ourania.

\section{Acknowledgments}

I would like to thank my advisor Namrata Narula for assisting me with this topic.

\section{References}

Baragwanath, E. (2010). Xenophon's Foreign Wives. In V. J. Gray (Ed.), Xenophon (Oxford Readings in Classical Studies) (pp. 41-72). Oxford University Press.

Danzig, G. (2017). Xenophon's Symposium. In M. A. Flower (Ed.), The Cambridge Companion to Xenophon (pp. 132-151). Cambridge University Press.

Dorion, L.-A. (2017). Xenophon and Greek Philosophy. In M. A. Flower (Ed.), The Cambridge Companion to Xenophon (pp. 37-56). Cambridge University Press.

Ferrario, S. B. (2017). Xenophon and Greek Political Thought. In M. A. Flower (Ed.), The Cambridge Companion to Xenophon (pp. 57-83). Cambridge University Press.

Gray, V. J. (1992). Xenophon's Symposion: The Display of Wisdom. Hermes, 120(1), 58-72.

Gray, V. J. (2017). Xenophon's Language and Expression. In M. A. Flower (Ed.), The Cambridge Companion to Xenophon (pp. 223-240). Cambridge University Press.

Guthrie, W.K.C. (1971). Socrates. Cambridge University Press.

Hindley, C. (2010). Xenophon on Male Love. In V. J. Gray (Ed.), Xenophon (Oxford Readings in Classical Studies) (pp. 72-110). Oxford University Press.

Huss, B. (2010). The Dancing Sokrates and the Laughing Xenophon, or the Other Symposium. In V. J. Gray (Ed.), Xenophon (Classical Readings in Classical Studies) (pp. 257-282). Oxford University Press. 
Johnstone, C. L. (2009). Listening to the Logos: Speech and the Coming of Wisdom in Ancient Greece. University of South Carolina Press.

Kamtekar, R. (2013). Ancient Virtue Ethics: An overview with an emphasis on practical wisdom. In D. C. Russell (Ed.), The Cambridge Companion to Virtue Ethics (pp. 29-48). Cambridge University Press.

Krinks, P. (2018). Pausanian Classification or Socratic Participation: Theologizing the Plurality of Erotic Praxis is Plato's Symposium. Religions, 9(9).

Lear, A., \& Cantarella, E. (2008). Images of Ancient Greek Pederasty: Boys Were Their Gods. Routledge.

Lee, J. W. I. (2017). Xenophon and his Times. In M. A. Flower (Ed.), The Cambridge Companion to Xenophon (pp. 15-36). Cambridge University Press.

Luraghi, N. (2017). Xenophon's Place in Fourth-Century Greek Historiography. In M. A. Flower (Ed.), The Cambridge Companion to Xenophon (pp. 84-100). Cambridge University Press.

Okin, S. M. (1977). Philosopher Queens and Private Wives: Plato on Women and the Family. Philosophy and Public Affairs, 6(4), 345-369.

Plato. (2008). The Symposium (M. C. Howatson \& F. C. C. Sheffield, Eds.; M. C. Howatson, Trans.). Cambridge University Press.

Rood, T. (2017). Xenophon's Narrative Style. In M. A. Flower (Ed.), The Cambridge Companion to Xenophon. Cambridge University Press.

Xenophon. (1890). The Symposium (H. G. Dakyns, Trans.). Macmillan and Co. 